\title{
Wspomnienie o Profesorze Marku Nowackim
}

W ostatnich dniach lipca 2014 roku odszedł od nas profesor Marek Paweł Nowacki, znany i ceniony chirurg onkolog oraz wieloletni pracownik i Dyrektor Centrum Onkologii — Instytutu im. Marii Curie-Skłodowskiej w Warszawie. Dzisiaj, po upływie ponad pół roku od Jego śmierci, chcielibyśmy przybliżyć Czytelnikom Nowotworów, zwłaszcza tym, którzy nie mieli okazji poznać Go osobiście, sylwetkę Profesora.

Profesor Marek Paweł Nowacki urodził się 23 marca 1938 roku w Katowicach. Był absolwentem Akademii Medycznej w Warszawie, którą ukończył w 1963 roku. Pracę w Instytucie Onkologii rozpoczął w 1965 roku. Zapewne wówczas poznał jednego z najwybitniejszych polskich chirurgów onkologów, profesora Tadeusza Koszarowskiego, którego postaći charyzma w znacznej mierze ukierunkowały Jego późniejsze zainteresowania. W 1969 roku M.P. Nowacki uzyskał specjalizację w dziedzinie chirurgii ogólnej, a rok później obronił doktorat. Wkrótce potem (1970-1971), za sprawą Profesora Koszarowskiego, odbył staż w jednym z najbardziej renomowanych ośrodków onkologicznych, jakim jest Istituto Nazionale dei Tumori w Mediolanie. W owym czasie kierował nim światowej sławy onkolog Umberto Veronesi, którego prace w znaczącym stopniu zmieniły podejście do sposobu leczenia raka piersi. Kolejne lata kariery zawodowej M.P. Nowackiego skupiały się jednak na problematyce leczenia raka jelita grubego. Trzeba pamiętać, iż w tamtym okresie operacje raka jelita grubego wiązały się ze znacznie wyższym niż obecnie ryzykiem ciężkich powikłań, a w tym i śmiertelności pooperacyjnej. Pesymistycznie prezentowały się również wyniki onkologiczne. Dość wspomnieć, że odsetek nawrotów miejscowych po operacjach raka odbytnicy sięgał wówczas ponad 20\%. Dlatego też za przełomowe w karierze zawodowej M.P. Nowackiego było doświadczenie, jakie uzyskał po nostryfikacji dyplomu lekarza (1974). Certyfikat ECFMG (Educational Council for Foreign Medical Graduates) pozwolił mu bowiem na podjęcie pracy w Stanach Zjednoczonych. Pracował w oddziałach specjalizujących się w leczeniu chorób jelita grubego Szpitala Deaconess w Buffalo, stan Nowy
Jork, USA (1974-1975), w Cleveland Foundation, Ohio,USA (1979), w Klinice Chirurgii Ogólnej Case Western Reserve University, Cleveland, Ohio, USA (1980), w Roswell Park Memorial Institute of Oncology w Buffalo, stan Nowy Jork, USA (1986) oraz w State University of New York at Stony Brook, USA (1988). Wspominając tamte lata na łamach Pulsu (Miesięcznika Okręgowej Izby Lekarskiej w Warszawie), Profesor Nowacki pisał: „Przeszedłem egzamin z chirurgii — podczas operacji weryfikowano każdy mój ruch. Trwało to cały dzień, ale skończyło się dla mnie dobrze. Zdobyłem uprawnienia chirurga ogólnego i mogłem samodzielnie pracować. Przez rok byłem chief rezydent (szefem rezydentów) i miałem sześciu podwładnych. Ja, cudzoziemiec! Językiem może nie władałem doskonale, ale umiejętności chirurgicznie miałem duże. Szkoła chirurgii, jaka dostałem w Warszawie, była dobrą odskoczniq. W pierwszym roku pracy w USA zoperowałem cztery razy więcej przypadków zwiqzanych z jelitem grubym niż cały nasz zespół pracujący przy Wawelskiej. To było ważne doświadczenie".

To doświadczenie zaowocowało uzyskaniem kolejnych stopni i tytułów naukowych (1982 — stopień doktora habilitowanego, 1989 - tytuł profesora). Był już wówczas niekwestionowanym autorytetem $w$ dziedzinie chirurgii nowotworów jelita grubego. Naturalną konsekwencją tego było również objęcie przez Profesora Nowackiego w 1995 roku stanowiska Kierownika nowo powstałej Kliniki Nowotworów Jelita Grubego w Centrum Onkologii na warszawskim Ursynowie. Autor niniejszych wspomnień był jednym z lekarzy (wówczas dopiero adeptem chirurgii po I stopniu specjalizacji), którzy wraz z Profesorem przeszli z Instytutu Onkologii na Wawelskiej do nowo powstałej kliniki. Należy w tym miejscu powiedzieć, iż większość lekarzy, którzy weszli w skład zespołu tworzącej się kliniki, miało wówczas jeszcze niewielkie doświadczenie w chirurgii raka jelita grubego. Dlatego pierwsze lata naszej pracy pod kierownictwem Profesora Nowackiego to dla wielu z nas lata nauki zawodu lekarza, chirurga, onkologa. Profesor Nowacki wychodził z założenia, iż nie nauczymy się chirurgii jedy- 
nie asystując przy operacji, toteż pierwsze operacje, które przyszło nam wykonywać, odbywały się pod Jego okiem i z Jego pomocą. Każdemu z nas, a zwłaszcza tym, którzy stawiali dopiero pierwsze kroki w chirurgii onkologicznej, poświęcał mnóstwo czasu, ucząc nas nie tylko samej sztuki operowania, ale również wszystkiego, co składa się na leczenie chorego z chorobą nowotworową. Powtarzał nam, że chirurg leczy niekiedy tylko objaw choroby, zaś sama choroba nowotworowa wymaga kompleksowej terapii. Jednocześnie zwracał nam uwagę, iż błędy które może popełnić chirurg operujący chorego na raka jelita grubego (bądź też każdy inny nowotwór) rzutują potem na całokształt leczenia onkologicznego i na jego wyniki. Starał się nas nauczyć krytycznego podejścia do wyników własnej pracy, ale też uczył samodzielności w podejmowaniu decyzji przy stole operacyjnym, czyli tego, co niezbędne, aby po pewnym czasie stać się samodzielnym chirurgiem. Nie żądał bezwzględnego naśladowania Jego własnych manewrów chirurgicznych, ale jednocześnie pedantycznie przypominał nam o zachowaniu standardów techniki chirurgicznej. Jednocześnie zachęcał i motywował nas do pracy naukowej. Dość powiedzieć, że w ciągu pierwszych 5 lat pracy pod kierownictwem Profesora połowa zespołu lekarzy uzyskała stopień doktora nauk medycznych, a do 2002 roku wszyscy zdobyli specjalizacje w dziedzinie chirurgii onkologicznej. Okres działalności kierowanej przez Niego kliniki przypadł też na czas niezwykle istotnych zmian, jakie dokonały się w leczeniu raka jelita grubego, a szczególnie raka odbytnicy. Upowszechnienie techniki całkowitego usunięcia mezorektum (TME), wprowadzenie standardu radioterapii przedoperacyjnej, nowe programy lekowe z wykorzystaniem nowych cytostatyków i przeciwciał monklonalnych, wszystko to sprawiło, że wyniki leczenia onkologicznego u chorych na raka jelita grubego uległy znaczącej poprawie. Wystarczy powiedzieć, iż odsetek nawrotów miejscowych po radykalnych operacjach raka odbytnicy spadł do poziomu poniżej 10\%, a przeżycia 5-letnie chorych leczonych w klinice kierowanej przez Profesora Marka Nowackiego sięgnęły 70\%. I tutaj znowu Profesor Nowacki zwykł wspominać, iż pierwowzór techniki TME nakreślił już w latach sześćdziesiątych wspominany wcześniej Jego nauczyciel — Profesor Tadeusz Koszarowski, określając ją jako „operację międzypowięziową". Ostatnie dziesięć lat aktywności zawodowej Profesora Nowackiego przypadły na okres, kiedy piastował on stanowisko Dyrektora Centrum Onkologii. To również lata, kiedy obowiązki związane z pełnioną przez Niego funkcją w coraz większym stopniu "odbierały" mu czas na to, co było mu najbliższe — operowanie chorych. Pomimo to znajdował zawsze czas, aby każdego ranka pojawić się w klinice. Zawsze można było liczyć na Jego wsparcie, zawsze znalazł czas na skonsultowanie trudnego przypadku, zawsze służył radą.

Kreśląc biografię Profesora Nowackiego, należy też dodać, iż w latach 1986-1997 pełnił funkcję Konsultanta Krajowego w dziedzinie onkologii. Opublikował ponad 200 prac naukowych w pismach o zasięgu międzynarodowym, a wśród nich 32 w języku angielskim. Był członkiem Polskiego Towarzystwa Onkologicznego (od 1974), Towarzystwa Chirurgów Polskich (od 1979), Polskiego Towarzystwa Chirurgów Onkologów (od 1983 — członek założyciel, sekretarz 1983-92, prezes 1993-97), Polskiego Towarzystwa Onkologii Klinicznej (od 1995, członek honorowy od 2001), Polskiej Unii Onkologii (od 2000 — członek założyciel), Europejskiego Towarzystwa Chirurgii Onkologicznej (od 1986, członek zarządu w latach 1994-1998), International Society of University Colon and Rectal Surgeons (od 1994), American Society of Clinical Oncology (od 2002). Ponadto w latach 1996-2000 był delegatem do Światowej Federacji Towarzystw Chirurgii Onkologicznej.

Opisując sylwetkę profesora Nowackiego, nie sposób nie wspomnieć o Jego wielkiej pasji, jaką była fotografia. Być może niewiele osób wiedziało, że już od 1965 roku był członkiem Związku Polskich Artystów Fotografików. O sztuce fotografii potrafił opowiadać godzinami. O ile dla laika w tej dziedzinie (chociażby takiego jak autor tych wspomnień) większość z używanych przez Niego terminów, określeń, opisów szczegółów wpływających na jakość wykonanego zdjęcia mogła wydawać się niezrozumiała, to całkowicie rekompensowały to obrazy przyrody, krajobrazów, drzew, chmur, uwiecznione przez obiektyw aparatu Profesora.

Profesor Marek Paweł Nowacki przeszedł na emeryturę w 2010 roku. Wkrótce potem, kierowana przez Niego Klinika Nowotworów Jelita Grubego została przekształcona w Klinikę Nowotworów Układu Pokarmowego, a w 2012 roku włączona w skład Kliniki Gastroenterologii Onkologicznej. Pod koniec 2013 roku zdiagnozowano u Profesora chorobę nowotworową. Jako jednemu ze współpracowników i uczniów Profesora dane było mi być wśród tych, którzy towarzyszyli mu w Jego ostatnich tygodniach życia. Walkę z chorobą przegrał 29 lipca 2014 roku, żegnany przez Najbliższych i współpracowników, którzy zachowują Go w serdecznej pamięci.

\section{Dr hab. n. med. Andrzej Rutkowski}

Klinika Gastroenterologii Onkologicznej Centrum Onkologii — Instytut im. Marii Skłodowskiej-Curie w Warszawie e-mail:az.rutkowski@onet.eu 